\title{
Determinants of Entrepreneurship Success: An Examination of Chinese-Owned Businesses in Congo Brazzaville
}

\author{
Edwige Kamitewoko \\ Centre of Research and Prospective Studies/Faculty of Economy, Marien Ngouabi University, \\ Brazzaville, Congo \\ Email: aijiaae@yahoo.fr
}

Received May $8^{\text {th }}, 2013$; revised June $28^{\text {th }}, 2013$; accepted July $8^{\text {th }}, 2013$

\begin{abstract}
Copyright (C) 2013 Edwige Kamitewoko. This is an open access article distributed under the Creative Commons Attribution License, which permits unrestricted use, distribution, and reproduction in any medium, provided the original work is properly cited.
\end{abstract}

\begin{abstract}
The determinants of Chinese entrepreneurship Success are widely studied in the economic literature in recent twenty years. However, in the case of Congo Brazzaville where immigrant entrepreneurship takes an important proportion in workforce, it remains an under researched area. By using the data from the Prospective Research Center Studies Survey questionnaire, this paper aims to provide clearer insights into this area. The study is based on Brazzaville which is the capital of Congo, a sensitive center of commerce and a nucleus of entrepreneurship activities; it identified the foundation factors that enable Chinese entrepreneurs to success in their entrepreneurship in Congo Brazzaville. Two hundred respondents were sampled and their responses were modeled using the logistic regression. The findings show that key factors, such as: guanxi, education, experience in trade and finance experience play an important role to the success in their entrepreneurship.
\end{abstract}

Keywords: Entrepreneurship; Logit; Success Factors; Chinese Immigrant; Congo Brazzaville

\section{Introduction}

Immigrant entrepreneurship in developing countries has received extensive scholarly and policy attention. Public interest in this topic is high as entrepreneurship is found to play an important role in economic development. Entrepreneurship gives immigrants social dignity in the host country, but is also a very challenging initiative given the various obstacles they face.

Therefore, no matter the potential of success of their entrepreneurial project, it's difficult for new immigrants to find the start-up capital, and they generally must rely on the support of family and friends for this capital. Also, they can't easily hire employees from the mainstream society of their host country because their financial constraints don't allow them to pay the normal salaries and grant the usual benefits legally expected by employees. Consequently, they end up with very long work hours. There are many other obstacles immigrant entrepreneurs have to face in order to survive in the host countries. Unfortunately, for many years economist researchers have not focused on immigrant entrepreneurship, thus leaving the study of that phenomenon to anthropologists, managers and sociologists. However, after years of comparative neglect some researchers in economics have started to work on immigrant or ethnic entrepreneurship. Research on the economics of entrepreneurship - specially upon self-employment is beginning to expand. Microeconometric work includes Fuchs (1982), Rees and Shah (1986), Pickles and O'Farrell (1987), Borjas and Bronars (1989), Evans and Jovanovic (1989), and Evans and Leighton (1989). Even if that effort has started to make a difference in the literature, there still remains much to be known about the phenomenon of immigrant entrepreneurship especially in developing countries such as African countries which are receiving since the late 90, an increasing number of immigrants from Asian countries. The purpose of this paper is to contribute to the filling of this gap.

It is known that, Since China's engagement with Africa with regard to trade, investments, assistance, and - not least-diplomatic activities, the number of immigrants from china has been sharply increased. A recent article on Net Ease 2013 pointed out that in 2007, over 750,000 Chinese stayed or worked in Africa, this number reached more than 1 million in 2013. Congo Brazzaville didn't escape to this reality. Kamitewoko (2012) shows about 20.000 Chinese live in Congo Brazzaville in 2012, while they were about 10,000 in 2010. Like other recent immigrants group in Congo, a high proportion of Chinese immigrants are currently engaged in self-employed small business. These entrepreneurial activities serve further as a route of economic advancement and social mobility for the successful immigrant groups in their new host countries. Only, while some of the immigrants succeed in their entrepreneurship the others failed; which socio-economic characteristics explain the successful with regard to immigrant entrepreneurship? What are the determinants of successful Chinese immigrant entrepreneurship in Congo Brazzaville? Do observable characteristics explain their success, or is there a country-specific effect at work? Which are the driving factors leading to their success?

Our main objective focuses on the analysis of the factors leading to success of Chinese immigrant entrepreneurship.

One hypothesis is that high levels of education contribute to the success of Chinese entrepreneurs. Another hypothesis is that immigrant's entrepreneur's social networks are conducive 
to entrepreneurial success.

Regarding the area of microeconomics, the approach is rather labour market oriented than business-oriented: we focus on the entrepreneur's occupational success rather than on the enterprise's performance. The central unit is the individual immigrant entrepreneur.

This study proposes to gain insight into the factors which lead Chinese immigrants to succeed as entrepreneurs. However, definitions of entrepreneurship differ widely (Van Praag, 1999). For instance, Schumpeter (1949) defined entrepreneurs as people who were able to change a new idea into successful innovative ventures. Yet, Gartner (1985) sees it as the creation of new businesses, while Kirzner (1979) defines it as people who are looking out for new opportunities. This is a problem in entrepreneurship studies and it should be noted that because of this weakness, direct comparability between studies becomes difficult (Carland, Hoy, \& Carland, 1988). McCarthy and NichollsNixon (2001) argued that researchers should clearly state the definition being used in their study. In the light of this statement, this study therefore defines an entrepreneur as a person who has a registered business and employs at least one person.

This paper is structured as follows: Following this introduction, Section 2 contains a concise review of previous work, We present Chinese entrepreneurs in Congo Brazzaville in Section 3. Section 4, contains the methodology and data description. In the following Section; we portray the evidence gathered from the regressions and present the results. Finally, in the last section, we synthesize our findings.

\section{Literature Review}

According to Organization of Economic Cooperation and Development (OECD, 2003) entrepreneurship is a process through which entrepreneurs create and grow enterprises to provide new products or services, or add value to products or services. According to them, the characteristics of seeking opportunities, taking risk beyond security and having tenacity to push an idea through to reality combined into special persfective that permeates entrepreneurs.

Numerous studies reported on the research related to the factors leading to business success and revealed that there is a strong link between managerial skills and business success (Chu, Benzing, \& McGee, 2007; Benzing, Chu, \& Szabo, 2005; Yusuf, 1995; Gosh, Kim, \& Meng, 1993). According to Huck and McEween (1991) Jamaican entrepreneurs' success depend on their understanding of customers' need, access to capital, support of family, and networking with friends from former schools and colleges. It should be noted that the importance of family to the success of a business in China can never be emphasized enough. Due to an extremely low level of funding available to small and medium-sized enterprises in the country, family members not only are the source of start-up funds, but entrepreneurs' wives and children are often asked to work when no reliable employees can be found (Liao \& Sohmen, 2001). Vietnamese entrepreneurs however believe that friendliness to customers, having a good product at a competitive price, good customer services and a reputation for honesty are especially important factors leading to business success (Chu \& Benzing, 2004). According to Cheng and Espiritu (1989) Koreans and Latinos share an "immigrant ideology" which considers hard work and frugality as keys to success in America. Many researchers pointed out that the success attained by Korean business owners is a result of hard work, long hours spent in their business (Bonacich, 1979; Kim, 1981; Light \& Bonacich, 1988; Min, 1988; Min \& Jaret, 1985; Young, 1983).

Being from certain ethnic groups also may enhance the probability of successful entrepreneurship. Iyer and Schoar (2008) look at the market for wholesale pens in India amongst three different ethnic groups. They found the Marwari group, known for being particularly business savvy, were better at fostering long term business relationships, especially within their own community, than other ethnic groups. Enrico Santarelli and Hien Thu Tran (2013) show that human capital strongly predicts firm success, with learning exhibiting a statistically significant positive association with operating profit, benefits from weak ties outweigh those from strong ties, interaction of human capital and social capital displays a statistically significant positive effect on new-firm performance.

Determinants of business success also vary in nature. For example, Kraut and Grambsch (1987); Kallerberg and Leicht (1991) found size of investment and access to capital (Cooper, 1985; Hisrich, 1990; Krueger, 1993; Lussiers \& Pfeifer, 2001; Raman, 2004; Panda, 2008) found experience of entrepreneur as factors affecting business success. Meng \& Liang (1996) found no impact of experience on business success. Hisrich, 1990; Kallerberg \& Leicht, 1991; Krueger, 1993, Rowe et al. 1993; Lussiers \& Pfeifer, 2001; Masuo et al., 2001; Thapa, 2007; Indarti \& Langenverg, 2008; found that the education has positive effect in business success. Minniti and Bygrave (2003) have stated that people with more education are not necessarily more entrepreneurial. Kraut and Grambsch (1987), Hisrich (1990) Kallerberg and Leicht, (1991), Krueger (1993), Rowe et al., (1993), Masuo et al., (2001) found that age and support networks have positive contributions in business. Zimmerrer and Scarborough (1998) pointed out that most of entrepreneurs in the United States start business during their $30 \mathrm{~s}$ and $40 \mathrm{~s}$, many researchers founded that there is no limit of age for their entrepreneurial aspirations. Age difference at the start of business seems to have no association to business success. According to Staw (1991), at the start of any business age is not a key factor, but with enough training and preparation, the earlier someone starts business the better. Staw (1991) also notes that age is related to business success if it includes both sequential age and entrepreneurial age. This means that the older an entrepreneur is, the more experiences in business he has. Age thus implies wide experience. Kallerberg and Leicht (1991), Rowe et al., (1993); Masuo et al., (2001); Rose et al. (2006) has stated that the success of the business depends on skills, and training. Cooper (1985), Green and Pryde (1989), Raman (2004) found that motivational factors such as initiatives, third party assistance, encouragement by family and friends, skill and economic conditions leads to the success of the entrepreneurs.

Bosma et al. (2009) in their effort to investigate the determinants of successful entrepreneurs adopted a multiple regression approach based on the ordinary least squares technique to measure the influence of each determinant on success, while controlling for the other determinants. They identified variables relating to human capital, financial capital, strategies for keeping up with the business, social capital and control variables (gender). Each success measures the relations between determinants and success. The study discovered that; the amount of human capital is especially important for determining duration and profit, while financial capital is especially related to employment. Social capital and strategies for retrieving relevant information seem to be about equally important for all success measures. Specifi- 
cally, entrepreneurs at higher age (age is used as a proxy to knowledge of the world) seem to make less profit and to create less employment than younger entrepreneurs do. However, the average duration of the founded firm is higher so also younger entrepreneurs have higher probabilities to quit the business early. The educational level of the entrepreneur also matters for success, though only when profits are considered. Experience is also important in determining success. Having had experience in the same sector as the newly founded business increases the probabilities of success in making profits and in surviving.

Despite the cumulating literature on determinants of successful immigrant entrepreneurship, there is no studies about Chinese immigrants to Congo Brazzaville establish own businesses, engage in self-employment and factors leading to their economic success hence the interest of this study.

\section{Chinese Entrepreneurs in Congo Brazzaville}

With China's interest in Africa also come Chinese immigrants. Mister Chen is one of those thousands of new arrivals to Brazzaville. He and his family moved from China's southern Wenzhou 温州 in Zhejiang province three years ago to come to Africa. When he first learned of the opportunity to come to Congo brazzaville, he admitted that he knew nothing about the country as was made clear by their decision to settle in the eastern Congolese city.

Upon arrival to Congo he was introduced to a "Chinese association" that would provide him the logistical and financial support for him to open a small shop in one of Brazzaville neighborhoods. These associations are critical to understanding the success of the Chinese, both here in Brazzaville and the world over. Just as Chinese immigrant associations in San Francisco and New York, the Chinese associations in Congo provide what is essentially a micro-loan to new immigrants and the necessary logistical support to open a small business. The association handles the legal paperwork, ensures the necessary bribes are paid to relevant neighborhood police and government authorities; connects the shop owner with a distribution network of Chinese importers to supply their business. Mister Chen said he arrived from China with "only a few dollars" but was able to get his start through the help of the association and personal connection (guanxi 关系).

In turn, as his business develops, he re-pays the association back in small increments until the loan is fully paid.

His business grew quickly; he made money and local friends. But after a few years he grew weary of the long buying trips to China. So he and his wife bought a large plot of land in Brazzaville. On it they constructed a spectacular Chinese-Korean restaurant, with private dining areas, karaoke rooms and a giant 100 -seat dining hall. To the side of the restaurant they built a bedroom, which became their home. The business prospered, and soon he started additional enterprises including a bakery, a firm selling flat-screen televisions and a security company. All of this couldn't be possible without guanxi.

"Chinese don't think, they just try without studying the market too much. Otherwise, the chance is gone," he says.

\section{Characteristics of Chinese Immigrant Entrepreneurs: Chinese Social Network, Professional and Technical Associations}

The growing scale and diversity of the Chinese immigrants' community in Brazzaville during the last ten years generated a proliferation of professional and technical associations. This proliferation corresponded with the growing visibility and success of Chinese run businesses.

However, despite this formalization, informal guanxi networks remain a key component in entrepreneurship success. The entrepreneurs themselves give this "guanxi" networks much credit.

\section{Guanxi Network}

Guanxi is a complex phenomenon. The Chinese phrase "guan$x i$ " consists of two characters; the character "guan" means a gate or a hurdle, and " $x i$ " refers to a tie, a relationship, or a connection. Guanxi literally means "pass the gate and get connected" (Lee \& Dawes, 2005). It has its roots in the cultural philosophy of Confucianism. Confucianism considers society as a huge network in which a person plays different roles. This is important, because in Chinese culture the collective is always considered more important than the individual. There are four kinds of basic relations in society: emperor-subject, father-son, husband-wife, friend-friend.

Depending on these four kinds of relations, society achieves a balance (Gao \& Tian, 2006), the Confucian ideal. Fan (2002) has identified a modern guanxi base, Family (e.g. kin and in-laws) Relationship by nature (e.g. from same town; classmate; same profession) Relationship acquired (e.g. friend).

Interestingly the first are blood ties but the second and third are social. Thus, even today, Confucian tradition defines individuals in relational terms (Yang, 1994). Unlike Christianity, which puts individuals in reference to God, Confucianism relates individuals to their significant others (Bian \& Ang, 1997). Thus Chinese society has been seen to be organized by concentric guanxi circles, extending outwards from the family (the core) to relatives, friends (Don \& Dawes, 2005). The web of these obligations can be seen as the fabric of Chinese society.

Guanxi form the bases around which all social structures are embedded in China (Bian, 1994). Resultingly, the Chinese maintain that having good guanxi is synonymous with positive functioning in society (Luo, 2000; Tsui \& Lau, 2002; Yang, 1957). Consistent with this theme, the current Chinese management literature consistently highlights the importance of guanxi as crucial to business success in China (Farh et al., 1998; Tsang, 1998; Wall, 1990, Yeung \& Tung, 1996). Additionally, China is the largest, fastest growing transition economy and the most heavily engaged in international business (Child \& Tse, 2001). Taken in conjunction with one another, these two insights hold important implications for business in China. Essentially, guanxi are vital to successful business in the world's largest, fastest growing transition economy.

Bian (1997) suggests that the most important characteristic of guanxi is the reciprocal obligation to exchange favors. Failure to reciprocate favors may result in the loss of one's guanxi network and the multiple resources embedded in it, so guanxi relationships are long-term and the parties may not have any requirement for immediate return (Li \& Wright, 2000; Millington et al., 2006).

\section{Data Description and Methodology}

\section{Data}

We have access to the Centre of Research and Prospective Studies survey data which were collected in two step: first step, from January 2009 to February 2009, and the second from 
January 2013 to February 2013 in Brazzaville, data consisting of 200 Chinese entrepreneurs who started a business in 2009. The respondents gave detailed information on themselves, on their environment and on their strategies. Of the 200 entrepreneurs, 116 were men and 84 were women. They were allowed to express their views in the language with which they were most confortable (English or Mandarin Chinese).

The survey also provides a series of information about Characteristics of Business Owners (CBO) to explore the role that human capital, financial capital and other factors play in contributing to the relative success of Chinese owned businesses. The CBO contains a large sample of Chinese-owned businesses and detailed information on the characteristics of both the business and the owner.

A migrant is defined as a household member who is working outside the country and has left his/her country of origin for at least one month and entrepreneur as a person who has a Registered business and employs at least one person. We restrict the samples to include individuals ages 25 - 66 .

For measuring entrepreneurs successful in business there are a numbers of methods such as: net profit after tax reduce, amount of tax paid during the last three years, rate of productivity (input-output ratio), current assets ratio (ratio of current assets to current debt), increase business capital, increase products, services and sale, keep working since three years ago and active in the business. In this study due to the difficulty of access to all those information and data, we use the last three indicators for measuring this success.

\section{Determinants of Success}

In this section we explore the determinants of successful entrepreneurship that arise from literature. The classic views on entrepreneurship produce possible success determinants for starting entrepreneurs. These are summarised in Table 1, which is taken from Van Praag (1999). In this study we shall empirically test proposed determinants that stem from these classical views, as well as some other determinants proposed in literature.

Table 1.

Determinants of successful entrepreneurship discussed by the classic authors (taken from Van Praag, 1999).

\begin{tabular}{cll}
\hline & \multicolumn{1}{c}{ Having success as entrepreneur } & $\begin{array}{c}\text { Start and be a successful } \\
\text { entrepreneur }\end{array}$ \\
\hline Cantillon & & $\begin{array}{c}\text { Alertness and foresight } \\
\text { Bear risk }\end{array}$ \\
Say & $\begin{array}{l}\text { Judgement, perseverance, } \\
\text { knowledge of the world, business } \\
\text { and occupation }\end{array}$ & Bear risk \\
& $\begin{array}{l}\text { Intelligence, general ability } \\
\text { (dependent on family background }\end{array}$ & \\
and education) & $\begin{array}{l}\text { Knowledge of the trade } \\
\text { Bear Risk; Leadership } \\
\text { Schumpeter }\end{array}$ & Father entrepreneur \\
Knight & $\begin{array}{l}\text { Ability to deal with uncertainty: } \\
\text { selfconfidence, } \\
\text { foresight,intellectual capacity } \\
\text { Kirzner }\end{array}$ & $\begin{array}{l}\text { Creativeness and leadership to } \\
\text { exploit } \\
\text { profit opportunities }\end{array}$ \\
\hline
\end{tabular}

Some general classification of the determinants will be clarifying. We make a distinction between determinants that are related to human capital, financial capital and social capital determinants.

\section{Determinants of Success: Operational Variables}

A large number of possible determinants came along in exploring literature review. Obviously, not all determinants can be included in our analysis.

Some items can simply not be measured, like "good luck". Others may not be included in the dataset. Moreover, some determinants could be constructed but were excluded in the process of estimation. The variables included are described in the framework of our classification (see Appendix). For each determinant some brief explanation and the definition are provided. Most determinants become operational as dummy variables.

\section{The Research Method}

A large amount of research has been completed on determining what leads to successful entrepreneurship, and the characteristics of the successful entrepreneur (Blanchflower, 1998; Evans \& Leighton, 1998). Given firm data on the characteristics of entrepreneur ventures, the standard choice from the economist's toolkit is to run probit or logit regressions (Harada, 2003). The dependent variable is a binary measure of entrepreneur success or no success, and the independent variables are potential explanations for success.

Formally, the model logistic regression model is that:

$$
\log =\frac{P(x)}{1-P(x)}=\beta_{0}+x \beta
$$

Solving for, this gives

$$
\mathrm{P}(x, b, w)=\frac{e^{\beta_{0}+x \beta}}{1+e^{\beta_{0}+x \beta}}=\frac{1}{1+e^{-\left(\beta_{0}+x \beta\right)}}
$$

A binomial logistic regression model was formulated to determine the relative impact of factors on an immigrant entrepreneur's success in a small business. The binomial logistic regression model is shown in (1).

$$
\text { success } *=x \beta+\varepsilon
$$

The estimated model can be viewed below, where the dependent variable is whether or not an immigrant entrepreneur succeeded in a business, $\alpha$ and $\beta$ are estimated coefficients.

$$
\begin{aligned}
& \text { success } * \alpha+\beta_{1} \text { AGE }+\beta_{2} \text { EDUC }+\beta_{3} \text { EXPSEC }+\beta_{4} \text { EXPTR } \\
& +\beta_{5} \text { EXPEMP }+\beta_{6} \text { FINEXP }+\beta_{7} \text { FINCAP }+\beta_{8} \text { CONPAR } \\
& +\beta_{9} \text { FAMLOAN }+\beta_{10} \text { ENTREF }+\beta_{11} \text { GUANXI }
\end{aligned}
$$

\section{Results}

The Statistical Package for Social Sciences (SPSS) was used for the analysis. We include the antecedent variables on financial experience as control variable.

The results of the estimation are presented in Tables $\mathbf{2}$ and $\mathbf{3}$.

From the above table, four independent variables in decreasing order of importance are obviously significant, namely: guanxi, education, experience in trade and finance experience. 


\section{E. KAMITEWOKO}

Guanxi, or relationships/connections with others, has been identified as playing a key role in business success in China.

A guanxi network as it was already mentioned above, helps a firm overcome the lack of resources to accommodate growth while alleviating substantial bureaucratic costs that would result from internalizing operations. In markets, people see one invisible hand-price, while in China, another hand guanxi, is seen as a potential solution for most problems of entering and operating in China. While guanxi plays the role as the "protocol," setting the rules governing the communication and the transfer of affection between individuals in Chinese societies, the teaching of Confucianism deeply rooted in effect constructs the norms of guanxi for its establishment and maintenance. Guanxi in Chinese society is the basis on which they exchange a lifetime of favors, resources, and business leverage. It projects a preference for cooperation, group decision-making, and relationships. Thus, the importance of guanxi and its networks lie in their emphasis on collectivism and group harmony, and in turn help the business to achieve an integrated success.

The important role that Guanxi plays can be summarized in the Chinese expression, "one more connection offers one more road to take" (Seligman, 182).

Education and guanxi influence positively entrepreneurship success; this findings confirm our hypotheses. Education is traditionally viewed as an investment for the future. There is abundant evidence in every-day life and scientific literature for the fact that the acquisition of education improves the future earnings and overall success of individuals (Angrist \& Krueger, 1999). They are generally regarded as rather original persons who may have learned their business skills without too much of formal education. There are numerous studies on various links between self-employment, education and the success of selfemployed (Chandler \& Hanks, 1994; Evans \& Leighton, 1990; Holtz-Eakin et al., 2000; Mosakowski, 1993). As in many studies, the coefficient on the variable education is highly significa-

Table 2.

Variables in the equation.

\begin{tabular}{cccccccc}
\hline & & B & S.E. & Wald & df & Sig. & Exp (B) \\
\hline Step 0 & Constant & 1.295 & .172 & 56.612 & 1 & .000 & 3.651 \\
\hline
\end{tabular}

Table 3.

Variables in the equation.

\begin{tabular}{|c|c|c|c|c|c|c|c|}
\hline & & B & S.E. & Wald & df & Sig. & $\operatorname{Exp}(\mathrm{B})$ \\
\hline \multirow{11}{*}{ Step $1^{\mathrm{a}}$} & AGE & .168 & .242 & .481 & 1 & .488 & 1.183 \\
\hline & EDUC & 1.474 & .550 & 7.184 & 1 & .007 & 4.368 \\
\hline & EXPSEC & .055 & .507 & .012 & 1 & .913 & 1.057 \\
\hline & EXPTR & 1.541 & .540 & 8.153 & 1 & .004 & 4.668 \\
\hline & EXPEMP & .823 & .595 & 1.913 & 1 & .167 & 2.278 \\
\hline & FINEXP (1) & 1.539 & .550 & 7.841 & 1 & .005 & 4.661 \\
\hline & CONPAR & .143 & .571 & .063 & 1 & .803 & 1.154 \\
\hline & FAMLOAN & .336 & .525 & .408 & 1 & .523 & 1.399 \\
\hline & ENTREF & -.296 & .514 & .332 & 1 & .564 & .744 \\
\hline & GUANXI & 3.977 & .627 & 40.230 & 1 & .000 & 53.363 \\
\hline & Constant & -4.692 & 1.531 & 9.394 & 1 & .002 & .009 \\
\hline
\end{tabular}

Note: ${ }^{a}$ Variable(s) entered on step 1: AGE, EDUC, EXPSEC, EXPTR, EXPEMP, FINAEXP, CONPAR, FAMLOAN, ENTREF, GUANXI. tive indicating the importance of formal educational policies as feeding entrepreneurial success. Education increases an individual's propensity to entrepreneurship success.

There is a positive relationship between entrepreneur's trade experience and their probability of success. These results are confirmed by the studies of Mirry (1998), Patrick Kreiser, Louis Marino, K. Mark Weaver (2003) and Covin, J. G., \& Slevin, D. P. (1991). In fact, Individuals with business ownership experience believed that the obstacles to launch and continues a business could be overcome as compared to individuals without business ownership experience.

Experience is important in determining success. Having had experience in trade as the newly founded business increases the probabilities of success in making profits and in surviving. Experience in self employment only matters for achieving higher profits. Financial experience is seen to be also favorable for the duration of the firm.

Prior experience has a direct and positive association with entrepreneurship success; this is particularly important in determining how difficult it is for migrants to assimilate into the host country in respect of, for example, education and past working experience.

\section{Conclusion}

Immigrant Self-employment and entrepreneurship are economic phenomena of significant importance.

Entrepreneurs are responsible for the success of their businesses and have to face up with definite challenges in doing so. To know what constitute critical determinants of Chinese immigrant entrepreneurship success data were collected from 200 entrepreneurs randomly selected respondents in Brazzaville, who were administered with structured questionnaires. Regression analyses of the findings showed the positive and significant impact factors of guanxi, education, experience in trade and finance experience.

This research may be of interest to policy makers, small business consultants and academics because it highlights key success factors relevant to Chinese based businesses and the challenges they face.

Following the findings of this research, future study may choose to investigate the determinant of location for immigrant economic activity by verify other interaction effects of entrepreneurs' networking.

\section{REFERENCES}

Angrist, J., \& Krueger, A. (1999). Empirical strategies in labour economics, handbook of labour economics. Amsterdam: Elsevier Publishers.

Benzing, C., Chu H. M., \& Callann, G. (2005). Regional comparison of the motivation and problems of Vietnamese entrepreneurs. Journal of Developmental Entrepreneurship, 10, 3-27. doi: $10.1142 / \mathrm{S} 1084946705000033$

Bian, Y., \& Ang, S. (1997). Guanxi networks and job mobility in China and Singapore. Social Forces, 75, 981-1005.

Bonacich, E., \& Modell, J. (1980). The economic basis of ethnic solidarity: Small business in the Japanese American community. Berkeley and Los Angeles: University of California Press.

Bosma, N., Acs, Z. Autio, E., Coduras, A., \& Levie, J. (2009). Global entrepreneurship monitor, 2008 executive report. Wellesley: Babson College.

Carland, J. W., Hoy, F., \& Carland, J. A. (1988). Who is an entrepreneur? Is a question worth asking. American Journal of Small Busi- 


\section{E. KAMITEWOKO}

ness, 12, 33-39

Cheng, L. C. \& Espiritu, Y. (1989). Korean business in black and hispanic neighborhoods: A study of intergroup relations. Sociological Perspectives, 32, 521-534. doi:10.2307/1389136

Child, J., \&Tse, D. K. (2001). China's transition and its implications for international business. Journal of International Business Studies, 32, 5-22. doi:10.1057/palgrave.jibs.8490935

Chu, H. M., \& Benzing, C. (2004). Vietnamese entrepreneurs: Motivation, problems, and success factors. Journal of Global Business, 15 , 25-33.

Chu, H. M., Benzing, C., \& McGee, C. (2007). Ghanaian and Kenyan entrepreneurs: A comparative analysis of their motivations, success characteristics, and problems. Journal of Developmental Entrepreneurship, 12, 295-322. doi:10.1142/S1084946707000691

Cooper, A.C. (1985). The role of incubator organizations in funding of growth oriented firms. Journal ofBusiness Venturing, 1, 75-86. doi:10.1016/0883-9026(85)90008-4

Covin, J. G., \& Slevin, D. P. (1991). A conceptual model of entrepreneurship as firm behavior. Entrepreneurship Theory and Practice, 16, 7-25.

Evans, D. S., \&Leighton, L. S. (1990). Small business formation by unemployed and employed workers. Small Business Economics, 2, 319-330. doi:10.1007/BF00401628

Evans, D., \& Jovanovic, B. (1989). An estimated model of entrepreneurial choice under liquidity constraints. Journal of Political Economy, 97, 808-827. doi:10.1086/261629

Evans, D., \& Leighton, L. (1989). Some empirical aspects of entrereneurship. American Economic Review, 79, 519-535.

Fan, Y. (2002). Questioning guanxi, definitional, classification and implications. International Business Review, 11, 543-561. doi:10.1016/S0969-5931(02)00036-7

Farh, J. L., Tsui, A. S., Xin, K. R., \& Cheng, B. S. (1998). The influence of relational demography and guanxi: The Chinese case. Organization Science, 9, 471-487. doi:10.1287/orsc.9.4.471

Fuchs, V. (1982). Self-employment and labor force participation of older males. Journal of Human Resources, 17, 339-357. doi:10.2307/145584

Gao, Y. Q., \& Tian, Z. L. (2006). How Firms influence the government policy. Singapore Management Review, 28, 73-85.

Gartner, W. B. (1985). A conceptual framework for describing the phenomenon of new venture creation. Academy of Management Review, 10, 696-706.

Gibson, C. B., \& Gibbs, J. L. (2006). Unpacking the concept of virtuality: The effects of geographic dispersion, electronic dependence. Administrative Science Quarterly, 51, 451-495.

Gosh, B. C., Kim, T. S., \& Meng, L. A. (1993). Factors contributing the success of local SMEs: An insight from Singapore. Journal of Small Business and Entrepreneurship, 10, 33-45. doi:10.1080/08276331.1993.10600426

Green, S., \& Pryde, P. (1989). Black entrepreneurship in America. Transaction, New Brunswick, NJ: Transaction Publishers.

Hanks, S., \& Chandler, G. N. (1994). The impact of new venture growth research on entrepreneurship education. Frontiers in Entrepreneurship Research.

Hisrich, R. D. (1990). Entrepreneurship/intrapreneurship. American Psychologist, 45, 209-222. doi:10.1037/0003-066X.45.2.209

Holtz-Eakin, D., Rosen, H. S., \& Weathers, R. (2000). Foratio alger meets the mobility tables. Small Business Economics, 14, 243-274. doi:10.1023/A:1008128521851

Indarti, N., \& Langenberg, M. (2008). Factors affecting business success among SMEs: Empirical evidences from Indonesia. www.utwente.nl/nikos/archief/research/conferences/esu/papers/indar tilangenberg.pdf

Iyer, R., \& Schoar, A. (2008). Are there cultural determinants of entrepreneurship? Some NBER paper.

Kallerberg A. L., \& Leicht, K. T. (1991). Gender and organizational performance: Determinants of small business survival and success. Academy of Management Journal, 34, 136-161. doi:10.2307/256305

Kamitewoko, E. (2012). The determinant for choice of economic activities performed by Chinese migrants in Congo. Research paper of Center of Research and Prospective Studies.
Kirzner, I. (1979). Perception, opportunity and profit. Chicago, IL: University of Chicago Press.

Kraut, R.W., \& Grambsch, P. (1987). Home-based white collar employment: Lessons from the 1980, census. Social Forces, 66, 410426

Kreiser, P., Marino, L., \& Weaver, K. M. (2003). Assessing the relationship between entrepreneurial orientation, the external environment, and firm performance. The Stevens Institute of Technology Wesley J. Howe Award for Excellence in Research on the Topic of Corporate Entrepreneurship.

Krueger, N. (1993). The impact of prior entrepreneurial exposure on perceptions of new venture feasibility and desirability. Entrepreneurship: Theory and practice, 18, 5-21.

Lee, D. Y., \& Dawes, P. L. (2005). Guanxi, trust, and long-term orientation in Chinese business markets. Journal of International Marketing, 13, 28-56. doi:10.1509/jimk.13.2.28.64860

Lee, D. Y., \& Dawes, P. L., (2005). Guanxi, trust, and long-term orientation in Chinese business markets. Journal of International Marketing, 13, 28-56. doi:10.1509/jimk.13.2.28.64860

Li, J., \& Wright, P. (1999). The issue of guanxi: Discrepancies, reality and implications. BRC Working Paper 99036 Handler and Hanks, 1994.

Liao, D., \& Sohmen, P. (2001). The development of modern entrepreneurship in China. Stanford Journal of East Asian Affairs, 1, 27-33.

Light, I., \& Bonacich, E. W. (1988). Immigrant entrepreneurs: Koreans in Los Angeles. Berkeley and Los Angeles: University of California Press.

Luo, Y. D. (2000). Guanxi and business. Singapore City: World Scientific Publishing Co. Pte. Ltd.

Lussiers, R. N., \& Pfeifer, S. (2001). A crossnational prediction model for business success. Journal of Small Business Management, 30 228-239. doi:10.1111/0447-2778.00021

Masuo, D., Fong, G., Yanagida, J., \& Cabal, C. (2001). Factors associated with business and family success: Acomparison of single manager and dual manager family business households. Journal of Family and Economic Issues, 22, 55-73. doi:10.1023/A:1009492604067

McCarthy, A. M., \& Nicholls-Nixon, C. L. (2001). Fresh starts: Arnold cooper on entrepreneurship and wealth creation. The Academy of Management, 15, 27-36.

Meng, L. A., \& Liang, T. W. (1996). Entrepreneurs, entrepreneurship and enterprising culture. Paris: Addison-Wesley.

Millington, A., Eberhardt, M., \&Wilkinson, B. (2005). Gift giving, guanxi and illicit payments in buyersupplier relations in China: Analysing the experience of UK companies. Journal of Business Ethics 57, 255-268. doi:10.1007/s10551-004-6712-y

Min, P. G. (1988). Ethnic business enterprises: Korean small business in Atlanta. New York: Center for Migration Studies.

Minniti, M., \& Bygrave, W. D. (2003). National entrepreneurship assessment. United States of America Executive Report.

Mirry, A. (1995). A study of environmental factors on Marketing planning of Iran's small firms. Management Knowledge Journal, 33, 1-9.

Mosakowski, E. (1993). A resource-based perspective on the dynamic strategy performance relationship: An empirical examination of the focus and differentiation strategies in entrepreneurial firms. Journal of Management, 19, 819-839.

OECD (2006). Entrepreneurship and local economic development: Programme and policy recommendations, Local Economic and Employment Development (LEED), OECD Publishing. doi:10.1787/9789264199798-en

Panda, T. K. (2008). Entrepreneurial success key indicator analysis in Indian context.

http://dspace.iimk.ac.in/bitstream/2259/199/1/entrepreneurial+succes s.pdf

Pickles, A. R., \& O'Farrell, P. N. (1987). An analysis of entrepreneurial behavior from male work histories. Regional Studies, 21, 425-444. doi:10.1080/00343408712331344588

Raman, R. (2004). Motivating factor of educated self employed in Kerala: A case study of Mulanthuruthy Block Ernakulum Discussion Paper No. 90. Kerala Research Programme on Local Development Center for Development Studies.

Rees, H. \& Shah, A. (1986). An empirical analysis of self-employment 


\section{E. KAMITEWOKO}

in the UK. Journal of Applied Econometrics, 1, 95-108. doi:10.1002/jae.3950010107

Rose, R. C., Kumar, N., \& Yen, L. L. (2006). The dynamics of entrepreneurs' success factors in influencing venture growth. The Journal of Entrepreneurship and Sustainability, 11, 1-19.

Rowe, B. R. (1993). Introduction: Home-based family businesses. Family Business Review, 6, 351-354, 381-382. doi:10.1111/j.1741-6248.1993.00351.x

Santarelli, E., \& Tran, H. T. (2013). The interplay of human and social capital in shaping entrepreneurial performance: The case of Vietnam. Small Business Economics, 40, 435-458. doi:10.1007/s11187-012-9427-y

Schumpeter, J. A. (1949). Change and the entrepreneur. Cambridge: Harvard University Press.

Seligman, D. S. (1999). Chinese business etiquette: A guide to protocol, manners, and culture in the People's Republic of China. New York: Warner Books, Inc.

Staw, B. M. (1991). Psychological dimensions of organizational behavior. Sydney: MacMillan.

Thapa, A. (2007). Micro-enterprises and household income. The Journal of Nepalese Business Studies, 4, 110-118.

Tsang, E. W. K. (1998). Can guanxi be a source of sustained competitive advantage for doing business in China? Academy of Management Executive, 12, 64-73.

Tsui, A. S., \& Lau, C. M. (2002). Research on the management of enterprises in the People's Republic of China: Current status and fu- ture directions. In A. S. Tsui, \& C. M. Lau (Eds.), The management of enterprises in the People's Republic of China (pp. 1-27). Boston: Kluwer Academic Publishers. doi:10.1007/978-1-4615-1095-6

Tsui, A. S., Xin, K. R., \& Cheng, B. S. (1998). The influence of relational demography and guanxi: The Chinese case. Organization Science, 9, 471-487. doi:10.1287/orsc.9.4.471

Van Praag, C. M. (1999). Some classic views on entrepreneurship. De Economist, 147, 311-335. doi:10.1023/A:1003749128457

Wall, J. A. (1990). Managers in the People's Republic of China. Academy of Management Executive, 4, 19-32. doi:10.5465/AME.1990.4274792

Yang, L. S. (1957). The concept of pao as a basis for social relations in China. In J. K. Fairbank (Ed.), Chinese thought and institutions. Chicago, IL: University of Chicago Press.

Yang, M. M. (1994). Gifts, favors, banquets; The art of social relationships in China. New York: Cornell University Press.

Yeung, I., \& Tung, R. (1996). Achieving business success in confucian societies: The importance of Guanxi (connections). Organizational Dynamics, 25, 54-65.

Yusuf, A. (1995). Critical success factors for small business: Perceptions of South Pacific entrepreneurs. Journal of Small Business Management, 33, 68-73.

Zimmerer, T. W., \& Scarborough, N. M. (1998). Essentials of entrepreneurship and small business management (2nd ed.). New York: Prentice Hall 


\section{E. KAMITEWOKO}

\section{Appendix}

Explanatory Variables

\section{Human capital}

Age (AGE)

Education (EDUC)

Experience in the sector (EXPSEC)

Experience in trade (EXPTR)

Experience as an employee (EXPEMP)

2. Financial capital

Financial experience (FINEXP)

Contribution by business partner(s) (CONPAR)

Received loan from family (FAMLOAN)

3. Social capital

Entrepreneurs in the family (ENTREF)
Brief description and measure

Human capital relates to the intrinsic qualities and is thought to have a positive influence on the success of starting entrepreneurs. Knowledge is an important factor in this respect, which may be acquired through general education or through time.

The age of the entrepreneur can be considered as a measure for knowledge of the world. In the survey, the respondents were asked to state the age category they were in (intervals of 5 years). The age variable takes on the value of the mean of the age interval divided by 10. For example, if an entrepreneur is in the category $20-25$, the age variable takes on the value of 2.25 .

The level of education for the entrepreneur is important for business operations If an entrepreneur has experienced a high level of education (university or high-level vocational training), the dummy variable for education attains the value one (and zero otherwise). In the survey, people were asked to choose the highest education level they have completed.

This dummy variable indicates whether the respondent has experience in working in the same sector as he started business.

Kolvereid (1996) found that individual with prior business experience had significantly higher rate of success than those without such experience.

If the entrepreneur is already familiar with trade, this may enhance his results. The dummy variable attains the value of one if there is some experience in trade, and of zero otherwise.

Having experience as an employee may be beneficial to the starting entrepreneur, as it will enhance knowledge of business. The dummy variable equals one if the respondent has been an employee and zero if this is not the case.

Almost every entrepreneur needs a substantial financial input. The financial resources of the starting entrepreneurship are therefore important.

Many questions regarding this topic are posed in the center of research and prospective studies survey.

Finance is an important aspect of entrepreneurship. Some knowledge on financing the business is almost a necessity. If the entrepreneur has some financial experience himself, the variable equals one (and zero otherwise).

Maybe a business partner makes some financial contribution. This partner will (possibly) benefit from the new business. This will again be indicated using a dummy variable.

If the family comes to help in the financing part of starting business, this is indicated by another dummy variable.

In order to have success as an entrepreneur, the importance of communicating with relations seems to be growing and growing. Having capabilities in this respect can be indicated as owning social capitall. Also in literature, increased attention is paid on the relation between social capital and entrepreneurship.

Being influenced by self-employed members of the family can be a determining factor for success. For this, a variable is constructed that has value one if the entrepreneur reported considerable influence of self-employed family members, and zero if this is not the case.

An important way that people get access to information is through interaction with other people i.e networking and linkages (guanxi)

This variable indicates whether the entrepreneur has often (value equals one), or never (value equals zero) contacts with other entrepreneurs. 